\title{
Hubungan Kadar Feritin Serum dengan Gangguan Fungsi Paru Pasien Thalassemia Mayor Anak
}

\author{
Marte Robiul Sani, Cissy B. Kartasasmita, Lelani Reniarti \\ Departemen Ilmu Kesehatan Anak Fakultas Kedokteran Universitas Padjadjaran/Rumah Sakit Dr. Hasan \\ Sadikin Bandung
}

\begin{abstract}
Latar belakang. Gangguan fungsi paru merupakan komplikasi thalassemia yang sering dilupakan. Kelebihan besi yang ditandai peningkatan kadar feritin serum diduga merupakan penyebab terjadinya gangguan fungsi paru pada pasien thalassemia mayor.

Tujuan. Menganalisis hubungan kadar feritin serum dengan gangguan fungsi paru pasien thalassemia mayor anak serta menentukan batasan kadar feritin serum yang berhubungan dengan gangguan fungsi paru.

Metode. Penelitian cross-sectional dilaksanakan pada bulan April-Mei 2013. Dilibatkan 45 anak thalassemia mayor di Poliklinik Thalassemia RS Dr. Hasan Sadikin, Bandung. Setiap subjek dilakukan anamnesis, pemeriksaan fisis, kadar feritin serum, dan spirometri. Analisis hubungan kadar feritin serum dengan gangguan fungsi paru digunakan uji regresi logistik dengan pertimbangan variabel perancu serta kurva ROC untuk menentukan batasan kadar feritin serum yang berhubungan dengan gangguan fungsi paru.

Hasil. Sejumlah 45 anak memenuhi kriteria penelitian. Di antara 45 anak, 16 mengalami gangguan fungsi paru restriktif dengan derajat gangguan bervariasi, 11 anak gangguan ringan, 4 sedang, 1 berat, dan tidak ada yang mengalami gangguan fungsi paru obstruktif atau campuran. Rerata kadar feritin serum kelompok gangguan fungsi paru restriktif $(7.151,88 \mu \mathrm{g} / \mathrm{L})$ lebih tinggi dibandingkan kelompok paru normal $(3.450,34 \mu \mathrm{g} / \mathrm{L})$ dan kadar feritin $4.839 \mu \mathrm{g} / \mathrm{L}$ berhubungan dengan gangguan fungsi paru. Pada pasien thalassemia mayor anak didapatkan korelasi kadar feritin serum dengan gangguan fungsi paru ( $\mathrm{p}=0,000, \mathrm{OR}=50,754)$.

Kesimpulan. Terdapat hubungan bermakna kadar feritin serum dengan gangguan fungsi paru pasien thalassemia mayor anak dan kadar feritin $4.839 \mu \mathrm{g} / \mathrm{L}$ merupakan batasan kadar feritin yang berhubungan dengan gangguan fungsi paru. Sari Pediatri 2014;16(3):210-4
\end{abstract}

Kata kunci: kadar feritin serum, gangguan fungsi paru, thalassemia mayor

\footnotetext{
Alamat korespondensi:

Dr. Marte Robiul Sani. Departemen Ilmu Kesehatan Anak Fakultas Kedokteran Universitas Padjadjaran/Rumah Sakit Dr. Hasan Sadikin. Jl. Pasteur No. 38 Bandung 40163, Indonesia. Telp. (022) 2035957.

E-mail: marterobiulsani@yahoo.co.id
}

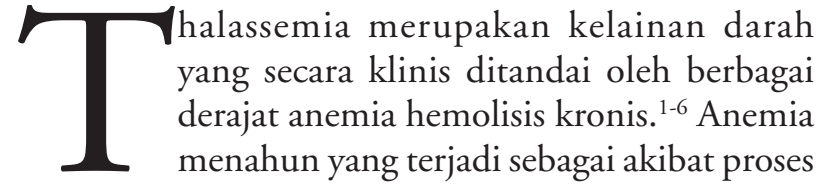


eritropoesis tidak efektif, proses hemolisis, dan reduksi sintesis hemoglobin menyebabkan pasien thalassemia memerlukan transfusi darah seumur hidup. ${ }^{4,7,8}$

Transfusi darah berulang dapat memperpanjang usia harapan hidup pasien thalassemia mayor, tetapi juga memberikan dampak negatif terjadinya kelebihan besi yang dapat menyebabkan berbagai kerusakan organ, termasuk paru. ${ }^{7,8}$ Gangguan fungsi paru merupakan komplikasi thalassemia yang sering dilupakan dan tidak dikenali. Berbagai variasi gangguan fungsi paru ditemukan pada pasien thalassemia mayor, mulai dari gangguan fungsi paru restriktif, obstruktif, atau campuran. ${ }^{9-10}$ Pemeriksaan kadar feritin serum merupakan cara yang paling sering digunakan untuk mengukur jumlah penimbunan besi dalam tubuh karena pelaksanaannya mudah, efek samping minimal, harganya relatif murah, dan cukup akurat. Kadar feritin serum meningkat sejalan dengan pertambahan akumulasi besi dalam tubuh. Kadar feritin serum dalam tubuh yang tinggi dapat memperkirakan gangguan organ yang mungkin terjadi. ${ }^{10}$ Batasan kadar feritin serum yang dapat menyebabkan gangguan fungsi paru belum diketahui dengan jelas.

Penelitian ini bertujuan menganalisis hubungan kadar feritin serum dengan gangguan fungsi paru pasien thalassemia mayor anak serta menentukan batasan kadar feritin serum yang berhubungan dengan gangguan fungsi paru.

\section{Metode}

Penelitian dilakukan secara observasi analitik dengan rancangan potong lintang (cross sectional). Pengambilan sampel dilakukan secara consecutive hingga jumlah subjek terpenuhi. Subjek penelitian adalah anak thalassemia mayor usia 6-14 tahun yang berobat jalan di Poliklinik Thalassemia Rumah sakit Dr. Hasan Sadikin, Bandung. Anak thalassemia mayor yang disertai penyakit infeksi dan inflamasi klinis serta memiliki riwayat penyakit paru kronis dieksklusi dari penelitian.

Variabel bebas adalah kadar feritin serum, sedangkan variabel tergantung adalah hasil uji fungsi paru yang meliputi normal, restriktif, obstruktif, dan campuran. Variabel perancu meliputi ukuran hepar, ukuran lien, dan gangguan pertumbuhan yang ditandai dengan tinggi badan berdasarkan usia $(\mathrm{TB} / \mathrm{U})<-2 \mathrm{SD}$. Dicatat pula karakteristik subjek penelitian yang meliputi umur, jenis kelamin, berat badan, tinggi badan, dan kelator besi yang digunakan.

Semua subjek dilakukan anamnesis, pemeriksaan fisis dan antropometri, pemeriksaan kadar feritin serum, serta pemeriksaan spirometri. Analisis statistik untuk menganalisis variabel yang berpengaruh terhadap fungsi paru dilakukan dengan uji univariat, meliputi TB/U dengan uji chi square test, ukuran hepar dan lien dengan uji Mann Whitney Test, serta kadar feritin serum dengan uji T-Test. Kemudian, dilanjutkan uji multivariat dengan uji regresi logistik untuk menganalisis hubungan kadar feritin serum dan gangguan fungsi paru dengan mempertimbangkan variabel perancu. Kurva ROC untuk menentukan batasan kadar feritin serum yang berhubungan dengan gangguan fungsi paru. Kemaknaan ditentukan berdasarkan nilai $\mathrm{p}<0,05$.

\section{Hasil}

Subjek berjumlah 45 anak, terdiri atas 23 laki-laki dan 22 perempuan. Usia subjek penelitian berkisar antara 6-14 tahun dengan rata-rata usia 10 tahun. Sebagian besar subjek penelitian hasil uji fungsi paru menunjukkan 29 anak dinyatakan normal dan 16 mengalami gangguan fungsi paru. Semua gangguan uji fungsi paru yang terjadi bersifat restriktif dengan derajat gangguan bervariasi. Sebelas anak mengalami gangguan ringan, 4 sedang, dan 1 berat, serta tidak ada yang mengalami gangguan fungsi paru obstruktif dan campuran. Karakteristik umum subjek berdasarkan hasil uji fungsi paru, meliputi jenis kelamin, umur, berat badan, tinggi badan, kadar $\mathrm{Hb}$, dan kelator besi yang digunakan tertera pada Tabel 1 .

Gangguan fungsi paru pada pasien thalassemia mayor anak dipengaruhi beberapa faktor, meliputi kadar feritin serum, gangguan pertumbuhan, serta ukuran hepar dan lien. Karakteristik subjek penelitian berdasarkan variabel yang berpengaruh terhadap fungsi paru tertera pada Tabel 2. Analisis statistik univariat menunjukkan hubungan bermakna kadar feritin serum dengan gangguan fungsi paru $(p=0,000)$ dan gangguan pertumbuhan yang dinilai dengan $\mathrm{TB} / \mathrm{U}$ juga menunjukkan hubungan bermakna $(p=0,003)$. Dengan demikian, secara statistik hubungan tersebut bermakna $(p<0,05)$. Sementara itu, variabel lain yang meliputi hepatomegali dan splenomegali tidak menunjukkan hubungan bermakna. Rerata kadar 
feritin serum kelompok gangguan fungsi paru restriktif $(7.151,88 \mu \mathrm{g} / \mathrm{L})$ lebih tinggi dibandingkan kelompok fungsi paru normal $(3.450,34 \mu \mathrm{g} / \mathrm{L})$.

Analisis statistik dengan uji regresi logistik untuk

Tabel 1. Karakteristik umum subjek penelitian berdasarkan uji fungsi paru

\begin{tabular}{lcc}
\hline \multirow{2}{*}{ Variabel } & \multicolumn{2}{c}{ Uji fungsi paru } \\
\cline { 2 - 3 } & $\begin{array}{c}\text { Normal } \\
\mathrm{n}=29\end{array}$ & $\begin{array}{c}\text { Restriktif } \\
\mathrm{n}=16\end{array}$ \\
\hline Jenis kelamin & & \\
$\quad$ Laki-laki & 14 & 9 \\
$\quad$ Perempuan & 15 & 7 \\
Umur & & \\
$\quad$ Rata-rata (tahun) & 10,55 & 9,6 \\
SD & 2,26 & 2,68 \\
TB & & \\
Rata-rata (cm) & 125,47 & 126,75 \\
SD & 12,26 & 12,19 \\
BB & & \\
Rata-rata (kg) & 26,66 & 27,03 \\
SD & 6,24 & 5,87 \\
Kadar Hb & & \\
Rata-rata (g/dL) & 7,89 & 7,22 \\
SD & 1,15 & 1,03 \\
Kelator besi & & \\
Deferipron & 24 & 11 \\
Deferasiroks & 4 & 4 \\
Desferoksamin & 1 & 1 \\
\hline
\end{tabular}

Tabel 3. Hasil akhir analisis regresi logistik kadar feritin serum

\begin{tabular}{lcc}
\hline Variabel & OR $(95 \% \mathrm{CI})$ & Nilai $\mathrm{p}$ \\
\hline TB/U & $0,114(0,017-0,760)$ & 0,052 \\
Kadar Feritin & $50,754(4,685-549,795)$ & 0,001 \\
\hline
\end{tabular}

$\mathrm{OR}=$ Odd Ratio

menilai kadar feritin serum sebagai faktor risiko kejadian gangguan fungsi paru dengan pertimbangan variabel perancu tertera pada Tabel 3 .

Selanjutnya, dilakukan penentuan titik potong kadar feritin serum dan uji fungsi paru dengan menggunakan kurva ROC untuk mendapatkan batasan kadar feritin serum yang mengarah kepada gangguan fungsi paru. Analisis mendapatkan titik potong kadar feritin serum $4.839 \mu \mathrm{g} / \mathrm{L}$ dengan sensitivitas $93,75 \%$, spesifitas $75,86 \%$ dan akurasi $84,44 \%$ yang secara statistik bermakna ( $\mathrm{p}=0,000),($ Gambar 1$)$.

\section{Pembahasan}

Gangguan fungsi paru pada thalassemia mayor telah diketahui dalam tiga dekade terakhir ini, tetapi mekanisme patogenesisnya belum sepenuhnya diketahui. Berbagai variasi gangguan fungsi paru ditemukan pada pasien thalassemia mayor, mulai dari gangguan fungsi paru restriktif, obstruktif, atau campuran. ${ }^{9-10}$ Pada penelitian ini, 16 di antara 45 anak mengalami

Tabel 2. Variabel-variabel yang berpengaruh terhadap fungsi paru

\begin{tabular}{|c|c|c|c|}
\hline \multirow[b]{2}{*}{ Variabel } & \multicolumn{2}{|c|}{ Uji fungsi paru } & \multirow[b]{2}{*}{$\mathrm{p}$} \\
\hline & $\begin{array}{c}\text { Normal } \\
\mathrm{n}=29\end{array}$ & $\begin{array}{c}\text { Restriktif } \\
\mathrm{n}=16\end{array}$ & \\
\hline $\mathrm{TB} / \mathrm{U}$ & & & $0,003^{*}$ \\
\hline Normal & 8 & 12 & \\
\hline Tidak normal & 21 & 4 & \\
\hline Ukuran Hepar & & & $0,230^{* *}$ \\
\hline Rata-rata $(\mathrm{cm})$ & 3,17 & 3,81 & \\
\hline SD & 1,31 & 1,64 & \\
\hline Ukuran lien & & & $0,748^{* *}$ \\
\hline Rata-rata (Schuffner) & 2,5 & 2,4 & \\
\hline SD & 1,52 & 1,14 & \\
\hline Kadar feritin & & & $0,000^{* * *}$ \\
\hline Rata-rata & $3.450,34$ & $7.151,88$ & \\
\hline SD & $1.487,65$ & $2.136,79$ & \\
\hline
\end{tabular}

chi square test ${ }^{*}$ Mann-Whitney test ${ }^{* *}$ T-test ${ }^{* * *}$ 


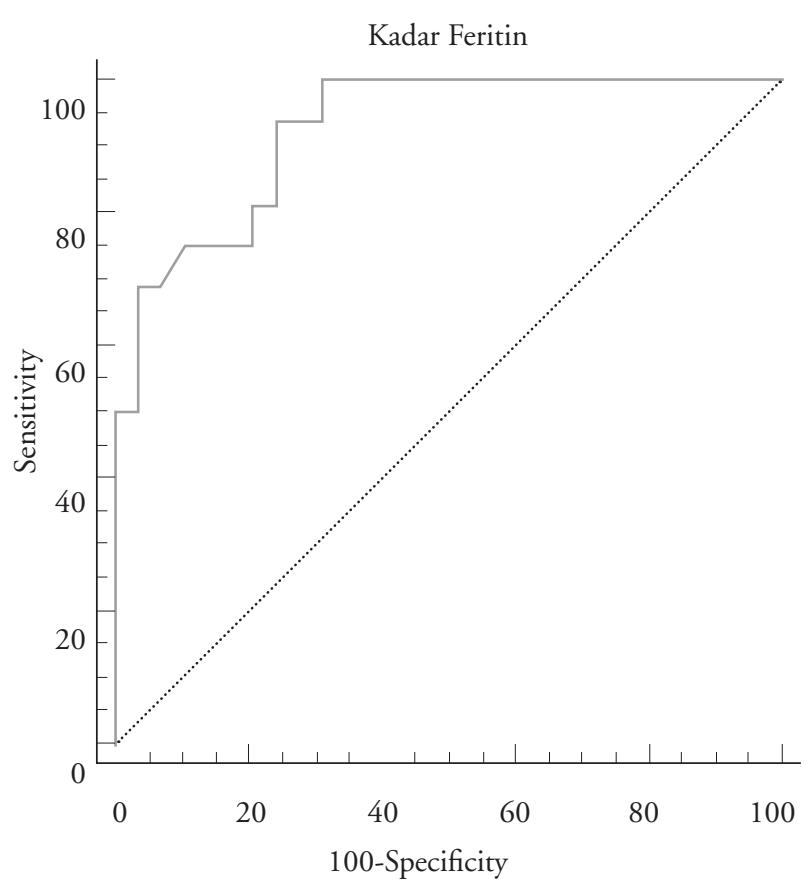

Gambar 1. Kurva ROC kadar feritin serum dengan uji fungsi paru

gangguan fungsi paru bersifat restriktif. Hasil tersebut sesuai dengan penelitian sebelumnya yang menunjukkan $38,46 \%$ kasus thalassemia anak dan remaja mengalami gangguan paru bersifat restriktif. ${ }^{11}$

Gangguan pertumbuhan merupakan salah satu komplikasi thalassemia yang dapat menyebabkan rongga dada tidak proporsional. ${ }^{4}$ Rongga dada yang tidak proporsional dapat menyebabkan gangguan volume paru sehingga terjadi gangguan fungsi paru restriktif. ${ }^{11}$ Pada pemeriksaan antropometri, sebagian besar subjek mengalami gangguan pertumbuhan. Analisis statistik univariat $\mathrm{TB} / \mathrm{U}$ terhadap gangguan fungsi paru menunjukkan hasil bermakna. Selanjutnya, hasil bermakna juga ditunjukkan dengan analisis multivariat regresi logistik. Hasil tersebut menunjukkan bahwa TB/U menjadi faktor protektif terhadap gangguan fungsi paru. Namun, hasil tersebut tidak sesuai dengan penelitian sebelumnya yang melakukan analisis regresi logistik terhadap faktor yang diduga menyebabkan gangguan, tidak terdapat hubungan $\mathrm{TB} / \mathrm{U}$ terhadap gangguan fungsi paru restriktif., ${ }^{11}$ Secara teori, gangguan pertumbuhan diduga menjadi faktor risiko gangguan fungsi paru pada thalassemia mayor anak. ${ }^{12}$ Berbeda dengan hasil penelitian ini yang menunjukkan bahwa gangguan pertumbuhan menjadi faktor protektif terhadap gangguan fungsi paru. Perbedaan hasil tersebut mungkin disebabkan karena gangguan pertumbuhan tidak terjadi di rongga dada, tetapi pada bagian tulang yang lain. Hal tersebut ditunjukkan dengan gangguan pertumbuhan yang lebih banyak terjadi pada subjek dengan fungsi paru normal.

Hepatomegali dan splenomegali dapat menghambat pergerakan diafragma yang mengakibatkan gangguan volume dan kapasitas paru sehingga terjadi gangguan fungsi paru restriktif. ${ }^{11,13}$ Pada penelitian ini tidak didapatkan hubungan antara hepatomegali dan splenomegali dengan gangguan fungsi paru. Hasil tersebut sesuai dengan penelitian Fung $\mathrm{dkk}^{13}$ yang menunjukkan hasil serupa.

Pada kelompok gangguan fungsi paru, rerata kadar feritin serum 7.151,88 $\mu \mathrm{g} / \mathrm{L}$, lebih tinggi dibandingkan kelompok fungsi paru normal, rerata 3.450,34 $\mathrm{g} / \mathrm{L}$. Analisis statistik univariat kadar feritin serum dengan gangguan fungsi paru menunjukkan hasil bermakna. Sementara itu, analisis multivariat dengan regresi logistik untuk menilai hubungan kadar feritin serum dengan gangguan fungsi paru dengan pertimbangan variabel perancu menunjukkan hubungan bermakna. Dengan demikian, kadar feritin serum mempunyai peluang 50,754 kali berhubungan dengan gangguan fungsi paru. Hal tersebut sesuai dengan penelitian sebelumnya yang menunjukkan hubungan antara peningkatan kadar feritin serum dengan gangguan fungsi paru restriktif pada thalassemia mayor. ${ }^{12,14,15}$

Hasil analisis ROC menunjukkan kadar feritin $4.839 \mu \mathrm{g} / \mathrm{L}$, merupakan batasan kadar feritin serum yang mengarah kepada gangguan fungsi paru. Hasil penelitian ini dapat dijadikan acuan untuk edukasi terhadap orangtua dan pasien thalassemia mayor tentang komplikasi gangguan fungsi paru yang mungkin terjadi akibat kadar feritin serum yang tinggi serta pentingnya pemberian kelator besi untuk mencegah kelebihan besi sehingga gangguan fungsi paru dapat dicegah.

Penelitian ini mempunyai kelebihan dan keterbatasan. Kelebihan penelitian ini adalah penelitian pertama di Indonesia, khususnya di RSHS, yang menghubungkan kadar feritin serum dengan gangguan fungsi paru pada kelompok pasien thalassemia anak. Pemeriksaan yang lebih akurat untuk menunjukkan adanya penimbunan besi dalam jaringan adalah menggunakan biopsi atau MRI, tetapi kelemahan pemeriksaan ini adalah harganya yang mahal dan saat ini pemeriksaan tersebut belum 
bisa dilakukan di Kota Bandung. Hal tersebut menjadi keterbatasan penelitian ini.

\section{Kesimpulan}

Terdapat hubungan yang bermakna antara kadar feritin serum dengan gangguan fungsi paru penderita thalassemia mayor anak. Kadar feritin $4.839 \mu \mathrm{g} / \mathrm{L}$ merupakan batasan kadar feritin serum yang mengarah kepada gangguan fungsi paru.

\section{Daftar pustaka}

1. Levine L. Thalassemia research and care: an update. Levine L, Sweeters N, penyunting. Edisi ke-1. Oakland: Children's Hospital \& Research Center Oakland; 2012.

2. Rachmilewitz EA, Giardina PJ. How I treat thalassemia. Blood 2011;118:3478-88.

3. Beutler E, Hoffbrand AV, Cook JD. Iron deficiency and overload. Hematol 2012;145:41-61.

4. Galanello R, Origa R. Beta-thalassemia. Orphanet J Rare Dis 2010;5:1-15.

5. Fleming RE, Bacon BR. Orchestration of iron homeostasis. N Eng J Med 2005;52:41-4.

6. Weatherall DJ. Talasemia in the next millennium. Ann NY Acad Sci 2010;850:1-9.

7. Papanikolaou, Pantopoulos K. Iron metabolism and toxicity. Toxicol and Appl Pharmacol 2005;202:1-13.

8. Karimi M, Emadmarvasti V, Hoseini J, Shoja L. Major causes of hospital admission in beta thalassemia mahor patients in Southern Iran. Iran J Pediatr 2011;21:50913.

9. Filosa A, Esposito V, Meoli I. Evidence of lymphocyte alveolitis by bronchoalveolar lavage in thalassemic patients with pulmonary dysfunction. Acta Haematol 2000;103:90-5.

10. Cooper D, Mansell A, Weiner M, Berdon W, Chetty B, Reid L, dkk. Low lung capacity and hypoxemia in children with thalassemia major. Am Rev Respir Dis 1980;121:639-46.

11. Bourli E, Dimitriadou M, Economou M, Viachaki E, Christoforidia A, Maratou E, dkk. Restrictive pulmonary dysfunction and its predictors in young patient with $\beta$-thalassemia major. Pediatr Pulmonol 2012;47:801807.

12. Filosa A, Esposito V, Meoli I, Stefanelli F, Cassandro R. Evidence of restrictive spirometric pattern in older thalassemic pateint. Respiration 2001;68:273-8.

13. Fung KP, Chow DKW, So SY, et al. Pulmonary function in thalassaemia major. J Pediatr 1987;111:534-7

14. Madden K, Khemani R, Newth C. Pediatric applied respiratory physiology - the essentials. Pediatr Child Health 2009:249-56

15. Carnelli V, Angelo E, Pecchiari M, Ligorio M, Angelo E. Pulmonary disfunction in transfusion dependent patient with thalassemia major. Am J Respir Crit Care Med 2002;168:180-4. 